TI 2007-029/3

Tinbergen Institute Discussion Paper

\title{
Analyzing a Flat Income Tax in the Netherlands
}

\author{
Bas Jacobs, 1,2,3,4,5 \\ Ruud A. de Mooij6,7,3,4,5 \\ Kees Folmer6
}

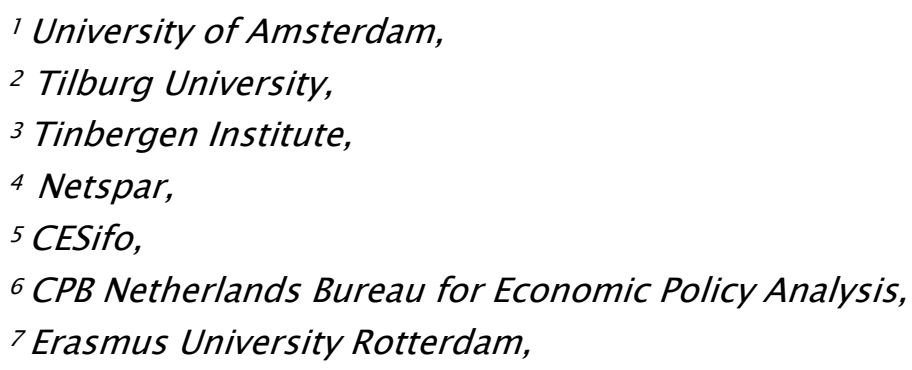




\section{Tinbergen Institute}

The Tinbergen Institute is the institute for economic research of the Erasmus Universiteit Rotterdam, Universiteit van Amsterdam, and Vrije Universiteit Amsterdam.

Tinbergen Institute Amsterdam

Roetersstraat 31

1018 WB Amsterdam

The Netherlands

Tel.: $\quad+31(0) 205513500$

Fax: $\quad+31(0) 205513555$

Tinbergen Institute Rotterdam

Burg. Oudlaan 50

3062 PA Rotterdam

The Netherlands

Tel.: $\quad+31(0) 104088900$

Fax: $\quad+31(0) 104089031$

Most TI discussion papers can be downloaded at http:/ /www.tinbergen.nl. 


\title{
Analyzing a Flat Income Tax in the Netherlands ${ }^{1}$
}

\author{
Bas Jacobs \\ University of Amsterdam, Tilburg University, Tinbergen Institute, CentER, \\ Netspar and CESifo (b.jacobs@uva.nl) \\ Ruud A. de Mooij \\ CPB Netherlands Bureau for Economic Policy Analysis, Erasmus University \\ Rotterdam, Tinbergen Institute, Netspar and CESifo ${ }^{2}$ \\ Kees Folmer \\ CPB Netherlands Bureau for Economic Policy Analysis (c.folmer@cpb.nl)
}

\begin{abstract}
A flat tax rate on income has gained popularity in European countries. This paper assesses the attractiveness of such a flat tax in achieving redistributive objectives with the least cost to labour market performance. We do so by using a detailed applied general equilibrium model for the Netherlands. The model is empirically grounded in the data and encompasses decisions on hours worked, labour force participation, skill formation, wage bargaining between unions and firms, matching frictions, and a wide variety of institutional details. The simulations suggest that the replacement of the current tax system in the Netherlands by a flat rate will harm labour market performance if aggregate income inequality is contained. This finding bolsters the notion that a linear tax is less efficient than a non-linear tax to obtain redistributive goals.
\end{abstract}

Key words: Flat tax; Labour market; General equilibrium; Equity; Optimal taxation.

JEL classification: D3, D5, H2

\footnotetext{
${ }^{1}$ We are grateful to Nicole Bosch for preparing figures 5.1 and 5.2.

${ }^{2}$ Corresponding author: Erasmus University Rotterdam, P.O. Box 1738, 3000 DR Rotterdam, The Netherlands, e-mail: demooij@few.eur.nl
} 


Introduction

Future trends put European welfare states under pressure. Skill biased technological change and internationalization of the worlds' production activities jeopardise the employment prospects of especially the low skilled. In addition, European governments face an increasing financial burden due to population ageing. This will boost public expenditures on old age provisions and health care. At the same time, globalization makes it increasingly difficult for governments to meet the rising need for public resources since tax bases become more elastic.

In order to maintain social cohesion and political support for broad welfare states, policy makers seek to boost employment, enhance education and improve labour market performance. Thus, governments aim to broaden the financial basis of collective provisions. In these policy discussions, it is sometimes argued that countries should replace their current progressive tax structures, characterized by rising marginal tax rates, by a flat income tax. ${ }^{3}$ For instance, in the German electoral campaign of 2005, Paul Kirchhof of the Christian Democratic Party used this argument to promote his flat tax proposal in Germany. In the Netherlands, proposals for a flat income tax have been suggested by e.g. the Council of Economic Advisors. A number of Eastern European countries have recently introduced flat income tax systems. In particular, Estonia and Lithuania introduced it in 1994 with rates of 26\% and 33\%, respectively. In 1995, Latvia followed with a flat rate of 25\%. Nowadays, Georgia (12\%), Russia and Ukraine (13\%), Serbia (14\%), Romania (16\%) and Slovakia (19\%) have all introduced flat income taxes (see Keen et al., 2006 for a review and discussion of the reforms in these countries).

This paper analyzes the impact of flat tax reforms for the income distribution and labour market performance in the Netherlands. We do so by using a detailed applied general equilibrium model for the Dutch economy. The model is empirically grounded in the data and encompasses decisions on hours worked, labour force participation, skill formation, wage bargaining between unions and firms, matching frictions, and a wide variety of institutional details.

Our main finding is that replacing the current tax structure by a flat income tax harms labour market performance if income inequality is contained through higher tax credits. This is reminiscent of the optimal tax literature, showing that linear taxes are less efficient than nonlinear taxes to reduce income inequality. A flat tax can raise labour market performance, but only if larger income inequality is tolerated. However, reforms with non-linear tax structures generally feature better labour market effects for the same increase in inequality.

\footnotetext{
${ }^{3}$ The flat tax is inspired by the ideas of Hall and Rabushka (1983). Their proposal contains first of all a single tax rate on all labour income. A fixed tax credit still renders the system progressive in the sense that the average tax burden rises with income. A second component of the Hall-Rabushka flat tax is a comprehensive business income tax, which includes a tax on interest, the return to equity and profits. Investment however, is fully tax deductible. Capital income is untaxed at the level of the capital owner. In this paper, we pay no attention to the second component of the Hall-Rabushka flat tax, i.e. the taxation of capital income. Instead, we focus on the first component, which is the single rate on labour income.
} 
The rest of this paper is organized as follows. Section 2 discusses the flat tax in the context of the theory of optimal income taxation. Section 3 explains the model that is used to explore the labour market implications of our tax reforms. Section 4 presents the analysis of two flat tax reforms in the Netherlands. Section 5 elaborates on other arguments for a flat tax, which cannot be assessed with the model. Finally, section 6 concludes.

\section{Optimal income taxation}

Like in other European countries, the Dutch government aims at reducing inequality. To that end, it uses progressive taxation and various social benefits and tax credits that may or may not depend on earned income. This redistribution does not come free. Indeed, income taxes reduce the price of leisure and household production relative to consumption, thereby inducing substitution away from labour supply towards untaxed activities. This reduces welfare in the presence of an income tax since the value of extra production from additional labour exceeds the social costs from foregone leisure. The government thus faces a trade-off between equity and efficiency.

In light of this trade-off between equity and efficiency, the question is how the government can obtain the best combinations between them. Following the seminal contribution by Mirrlees (1971), the literature on optimal taxation has tried to derive the optimal structure of the income tax in the presence of equity concerns and labour-supply distortions. It reveals that the optimal marginal tax schedule depends on four factors: (i) pre-tax income inequality; (ii) the degree of inequality aversion; (iii) the elasticity of labour supply; and (iv) the population density at various income levels. The first two indicators measure the benefits from redistribution. The latter two indicators determine the distortionary impact of marginal taxes. In particular, if elasticities are large or if density of households at a certain point in the distribution is high, marginal taxes are relatively distortionary in terms of aggregate labour supply.

Using actual pre-tax income distributions for the United States, a uniform and positive labour supply elasticity and different values for inequality aversion, Diamond (1998) and Saez (2001) show that the optimal income tax structure typically features a U-shaped pattern. ${ }^{4}$ Hence, for low incomes, the optimal marginal tax rate is high. Intuitively, benefits to the poor should be phased out with income in a range where population density is not so high, which is at the bottom. Beyond the minimum income level, the optimal marginal tax rate should be reduced for the densely populated middle groups. This avoids large aggregate labour supply distortions. For higher income levels, the marginal tax rises again if society features sufficient

\footnotetext{
${ }^{4}$ The earlier contributions conclude that the optimal marginal income tax is equal to zero at the very bottom and top of the income distribution (Seade, 1977). Tuomala (1990) shows, however, that these results are very local and of little practical relevance.
} 
aversion against inequality. Interestingly, actual marginal tax schedules feature a pattern as predicted by the optimal tax model. ${ }^{5}$

The literature on optimal non-linear income taxation shows that a non-linear structure of the marginal tax is more efficient than a linear structure, i.e. a flat tax. The reason is that the flat tax is informationally inferior to the non-linear tax because the government does not employ information on individual or household earnings under a linear income tax. With the same amount of dead weight loss, the non-linear tax structure redistributes more income than the linear income tax and vice versa (Saez, 2001).

While the traditional optimal tax literature favours non-linear tax structures over linear ones, it ignores some issues that are potentially relevant. These include endogenous participation distortions, heterogeneity in labour supply responses, distortions in human capital decisions and labour-market imperfections.

In the Mirrlees model without participation distortions, effective marginal tax rates are typically very large so as to phase out income dependent transfers. But, these high marginal tax rates for low income earners discourage workers to participate. Saez (2002) shows that participation distortions reduce the optimal marginal tax rates at the bottom of the income distribution to limit the distortions on job-search.

When human capital formation is endogenous, marginal income taxes have additional distortions, not only on the quantity of labour supply but also on the quality of labour supply. Jacobs (2005) and Bovenberg and Jacobs (2005) show that optimal marginal income taxes are substantially lowered when learning is taken into account. The main mechanism is that learning and working are complementary activities. Taxing labour incomes reduces labour supply and thereby implicitly taxes the returns from learning. Taxation also directly distorts human capital formation due to the presence of non-deductible investment costs.

Typically, optimal tax analyses have abstracted from labour market distortions. However, the presence of unions and search frictions reduces the dead weight costs of marginal tax rates. In particular, when government taxes away the wage increases at higher rates, unions moderate wage demands and workers who are looking for work are willing to accept lower wages. Both increase employment. Also, in contrast to the neoclassical labour market models, higher average tax rates, for given replacement rates, boost wage demands of unions and workers and this lowers employment (see for example, Bovenberg et al., 2000). The classical non-linear tax literature has not investigated these labour market distortions in depth. However, any analysis

\footnotetext{
${ }^{5}$ The older simulations in this literature typically found hump-shaped optimal tax schedules where marginal tax rates are generally declining with income over a wide range (cf. Tuomala, 1990). These simulations used bounded, synthetic lognormal distributions for skills and CES-utility functions with elasticities of substitution smaller than one, such that labour supply curves are backward bending at zero non-labour income. These features are less attractive from an empirical point of view. Actual income distributions are not bounded and appear to look more like the Pareto distribution especially near the top. The Pareto distribution eliminates the result of a zero marginal tax at the top as well, see Diamond (1998). And, labour supply generally features a non-negative uncompensated wage elasticity of labour supply, which rules out the backward bending labour supply curve.
} 
of tax reform in corporatist labour markets as the Netherlands, should take into account the potential effects of unions and search behaviour.

These issues raise the question whether a single income tax rate in the Netherlands could be optimal in the Dutch context or, at least, that it produces better labour market outcomes than the current system of rising marginal tax rates. This paper focuses on this latter question by analyzing reforms towards alternative flat income tax structures. In particular, we assess the income and labour market implications of these reforms by using a comprehensive computable general equilibrium model for the Netherlands. The model captures several mechanisms through which marginal tax rates affect labour market outcomes. Moreover, by using micro data on the Dutch income distribution, it sheds light on the distributional implications.

\section{An applied framework for the Netherlands}

To explore the implications of a flat income tax structure in the Netherlands for the income distribution and the labour market, we adopt a comprehensive general equilibrium framework for the Dutch economy called MIMIC. This model includes various labour market effects of taxation, such as effects on labour supply, human capital formation and equilibrium unemployment, see Graafland et al. (2001) for an extensive description of the model.

MIMIC fits in the class of applied general equilibrium models that are often used to explore the long-term influence of institutions on economic performance. It has been designed to explore the structural labour market implications of changes in the tax and social insurance system. Behavioural equations are explicitly derived from microeconomic principles such as utility maximization and profit maximization under the usual constraints. Thereby, it adopts broadly accepted economic theories in the modelling of labour-market imperfections, labour supply behaviour and job matching. In particular, MIMIC employs a union bargaining framework, combined with a skill-specific model for job search and matching. In this way, the model describes equilibrium unemployment in terms of the structure of the tax-benefit system, minimum wages, and social insurance. The theoretical foundation facilitates easy interpretation of simulation results in terms of rational microeconomic behaviour. Moreover, it enables us to explore large reform packages, without being vulnerable to the Lucas-critique.

A distinctive feature of MIMIC is a disaggregated household model aimed at adequately describing the impact of institutions on labour supply and the income distribution. In particular, the model accounts for heterogeneity in household composition by distinguishing 40 household types. It comprises a distinction with respect to single persons and couples, the presence of children in a household, the educational level of the primary and secondary earner, and whether household members participate or receive a certain type of social benefit. Moreover, the model distinguishes students and elderly people above 55 and those above 65 as separate groups. Within each of the 40 household types, we make a further distinction with respect to labour supply. In particular, individuals can choose between a limited set of discrete options of hours 
work per week. This enables the modelling of a high share of part-time work by secondary earners and single persons in the Netherlands. Within each option for a certain household type, we also employ an income distribution that is based on Dutch micro data. This allows us to precisely measure the number of people that would be affected by certain detailed policy measures. Indeed, the use of microdata enables us to simulate the macroeconomic impact of policy measures as a result of microeconomic responses by individual agents.

MIMIC has a firm empirical basis. Various crucial relationships in the model, including wage formation and the production functions, have been estimated from time series data. Furthermore, a meta analysis of micro econometric estimates on labour supply elasticities has been used to calibrate the labour supply model. This empirical base makes the model suitable for giving a quantitative assessment of policy reforms.

MIMIC pays close attention to the institutional details of the tax and social insurance systems. This makes the model especially relevant for policy analysis because actual policy proposals involve particular details of the Dutch tax and social-insurance systems.

To understand the labour-market outcomes from the MIMIC model, one should understand the key relationships between the income distribution, institutional variables, and labour-market performance in MIMIC. Knowledge about a limited number of modelling blocks suffices to understand most simulation results. These are the models for labour demand, labour supply, wage formation, and search-matching, see also Bovenberg et al. (2000) for a core version of MIMIC. The outcomes for various labour market variables can be understood as follows.

We present the labour supply effects for primary earners, secondary earners and single persons. For each of these individuals, labour supply responses are governed by standard income and substitution effects. If the marginal tax rate declines, for given average tax rate, labour supply increases. A lower average tax, for given marginal tax rate, exerts an income effect on labour supply, which is opposite from the substitution effect. Income effects are, however, smaller than substitution effects. Based on a meta-analysis, the uncompensated labour supply elasticities are set at 0.5 for secondary earners (mostly women), 0.1 for primary earners and 0.25 for singles (Evers et al., 2005). The participation decision of partners is endogenous so that we also present the impact on the female participation rate. Empirical studies suggest that participation distortions are indeed relatively important for aggregate labour supply (Blundell, 2001).

People choose the amount of on-the-job training. Accordingly, the skill composition of the labour force is endogenous. In particular, after-tax wage differentials determine the incentive for agents to improve their skill. Larger wage dispersion therefore encourages education and training and raises the share of skilled workers in the labour force. Based on empirical studies, the elasticity of skill premium is calibrated at 0.5, see e.g. Kuhry (1998). The costs of training are modelled as an effort cost, not in terms of foregone production.

Producer wages are determined by two components: contractual wages and top up wage costs per skill type. Contractual wages are obtained from a right-to-manage model in which 
firms and trade unions bargain over wages and where firms determine employment. Taxes and social benefits affect the wage bargaining process and determine the equilibrium rate of unemployment. Wages that are above the market clearing level lead to involuntary unemployment in equilibrium. Progressive income taxes can mitigate these pre-existing labourmarket imperfections and thus improve upon the efficient allocation. In particular, tax progression makes it less attractive for unions to bid for high wages because a larger share of wage claims is transferred to the government instead of the workers. Therefore, trade unions will reduce wage claims, thereby reducing involuntary unemployment. Empirical evidence supports this effect of tax progression on wages for a number of countries and in particular for the Netherlands (Tyrvainen, 1995; Graafland and Huizinga, 1999; Van Ewijk and Tang, 2000). Hence, while progressive taxes hurt welfare by reducing labour supply, participation and human capital, they can improve welfare by reducing equilibrium unemployment. Some degree of tax progression can therefore be efficient in an imperfect labour market. Based on estimations by Graafland and Huizinga (1999), the following reduced form elasticities apply in the wage equation in the initial equilibrium: average tax (+ 0.6), marginal tax $(-0.1)$, replacement rate $\left(^{+}\right.$ $0.3)$, consumer price $(+0.5)$. These estimates imply that reforms that reduce tax progression while leaving the overall tax burden unchanged cause higher equilibrium unemployment. If also the replacement rate falls, the effect is unclear though. The skill specific top up wage costs are determined in the search-matching model where the unemployed are matched with vacancies. Vacancies arise due to job quits in every period at an exogenous rate. Labour-market tightness, high reservation wages and minimum wage floors raise the search costs for new employees and thus increase unemployment.

The other parts of MIMIC are modelled in a fairly standard manner. The neo-classical production function contains capital, low-skilled labour and high-skilled labour as arguments. Cost minimizing firms determine their labour demand on the basis of relative prices for these inputs. The international product market is characterized by monopolistic competition. Hence, firms can set their prices as a mark-up over marginal costs. Since the export elasticity is finite due to the monopolistic market (a value of -2.0 on average), the country as a whole has some market power on international product markets. The government sector is modelled in substantial detail as it comes to the system of income taxation. Indeed, all relevant institutions are modelled and included in the government budget constrained. Policy parameters are exogenous in the model. See Graafland et al. (2001) for a more elaborate discussion of the rest of the model.

\section{$4 \quad$ Simulations of a flat tax}

Today, the Netherlands adopts a progressive tax structure in the personal income tax (see Table 4.1). In 2006, it contains a general tax credit of 1990 euro, a labour tax credit with a maximum of 1357 euro and several other credits targeted to specific groups. While the tax system is in 
principle individualized, this does not apply to the general tax credit. In particular, nonparticipating partners in couples can transfer their credit to their working spouse. The various tax credits imply that employed people do not pay tax for at least the first 10000 euro of their income. Beyond this level, a piecewise linear tax structure applies, with rates moving from $34.15 \%$ to $52 \%$. The highest rate is paid on incomes above 53000 euro.

\begin{tabular}{|c|c|c|c|c|}
\hline \multirow[t]{2}{*}{ Table 4.1} & Netherlands in & cluding em & yee insurances) $^{a}$ & \multirow[b]{2}{*}{ Taxable income } \\
\hline & Bracket length & Tax rate ${ }^{c}$ & Tax payers & \\
\hline \multicolumn{5}{|c|}{ Personal income tax (Box 1$)^{b}$} \\
\hline First bracket & 17046 & 34.15 & 5174 & 158.5 \\
\hline Third bracket & 21598 & 42.00 & 2171 & 24.8 \\
\hline Open bracket & & 52.00 & 425 & 8.7 \\
\hline General tax credit & \multicolumn{4}{|c|}{1990} \\
\hline Earned income tax credit & \multicolumn{4}{|c|}{ Maximum 1357} \\
\hline \multicolumn{5}{|c|}{${ }^{\mathrm{c}}$ The tax rates of the first two brackets comprise social security contributions at a rate of $31.70 \%$ for state old-age pension (aow: } \\
\hline \multicolumn{5}{|c|}{$\begin{array}{l}\text { 17.90\%), exceptional medical expenses (awbz: } 12.55 \% \text { ) and survivor benefits (anw: } 1.25 \% \text { ). Taxpayers over the age of } 65 \text { are not } \\
\text { required to pay aow contributions and face a tax rate in the first two brackets of } 16.25 \% \text { and } 23.55 \% \text { respectively. }\end{array}$} \\
\hline
\end{tabular}

We will explore two reforms in the current structure of the Dutch tax system by means of flat tax proposals. Thereby, the government budget is balanced ex-ante, i.e. before behavioural consequences are taken into account. The two versions differ with respect to the change in the tax rate and the general tax credit. In the first version, the credit remains unchanged. We thus simply impose a flat tax rate of $37.5 \%$, which is found to keep the government budget balanced ex ante. In the second flat-tax reform, we increase the general tax credit by 1400 euro and raise the flat tax rate to $43.5 \%$ to keep the government budget balanced ex-ante. ${ }^{6}$

In our analysis, we concentrate on two types of variables. First, we present the ex ante effect on the income distribution. To that end, we show scatter plots based on micro simulations for 40,000 Dutch households to demonstrate the income effects. Moreover, we compute the socalled Theil coefficient, which is an aggregate indicator for income inequality. The Theil coefficient equals 0 if all $N$ persons have the same income and its value is $\ln (N)$ at maximum in case all income accrues to one person. Second, we present the labour-market effects of the flat tax reforms according to simulations with the MIMIC model. In using MIMIC, we perform a

\footnotetext{
${ }^{6}$ We increase the tax credit only for people with a positive income, not for non-participating partners. This avoids overcompensation of single earner couples. In the simulations, we assume that there is no problem associated with take up of the credit, e.g. because the tax bill becomes negative. Hence, the credit can be interpreted as a payable transfer. In both reforms, we maintain the reduced rate in the first two brackets for the elderly above 65 . Hence, the tax structure for the elderly is not flat.
} 
comparative static analysis. The effects can be interpreted as the structural, long-term implications of the flat tax reforms.

\section{Impact on incomes}

Figure 4.1 shows the income effects of the reform towards a $37.5 \%$ flat income tax rate for a large number of households, distinguished in six groups: one-earner couples, double earner couples, single workers, single benefit recipients, retired couples and retired singles. The figures show the results from simulations for 40.000 households, where each point in the scatter represents one household. We see from Figure 4.1 that the flat tax is especially harmful to people with low incomes, which is due to the rise of the tax rate in the first bracket from $34 \%$ to $37.5 \%$. The reduction in income is around 4\% for couples around 25000 euro and for singles below this level of income. Singles and one-earner couples with a median income of around 29 500 euro also lose, but to a lesser degree than the lowest incomes. For incomes of around 31 000 euro, the reduction in the marginal rate in the second tax bracket more or less outweighs the higher rate of the first bracket, i.e. this is the break even point. Elderly people and those who depend on government assistance generally lose as they typically collect lower incomes than employees. People with high incomes gain, as much as 10 to $12 \%$ for the highest groups among working singles and couples. Overall, the flat tax reform is found to redistribute income from low to high incomes. The aggregate Theil measure rises by 6.5 percent.

Figure 4.1 Income effects according to household type of a 37.5\% flat tax in 2006 (\% changes)
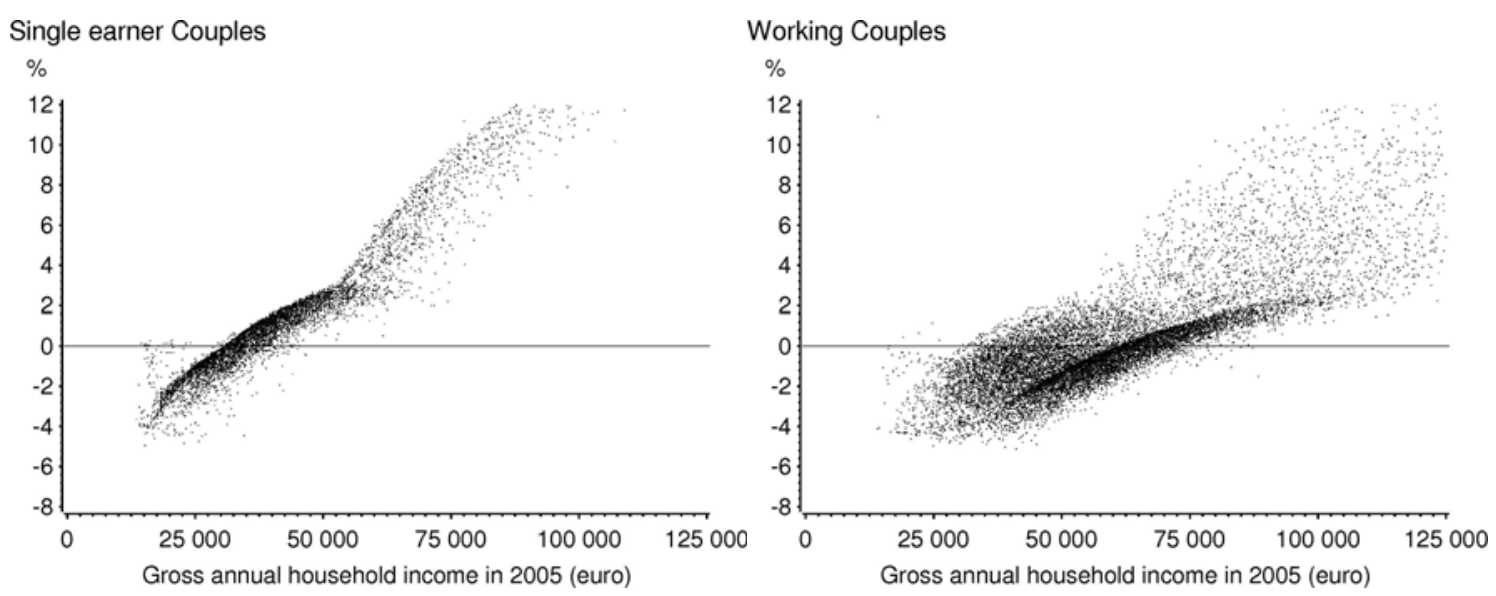

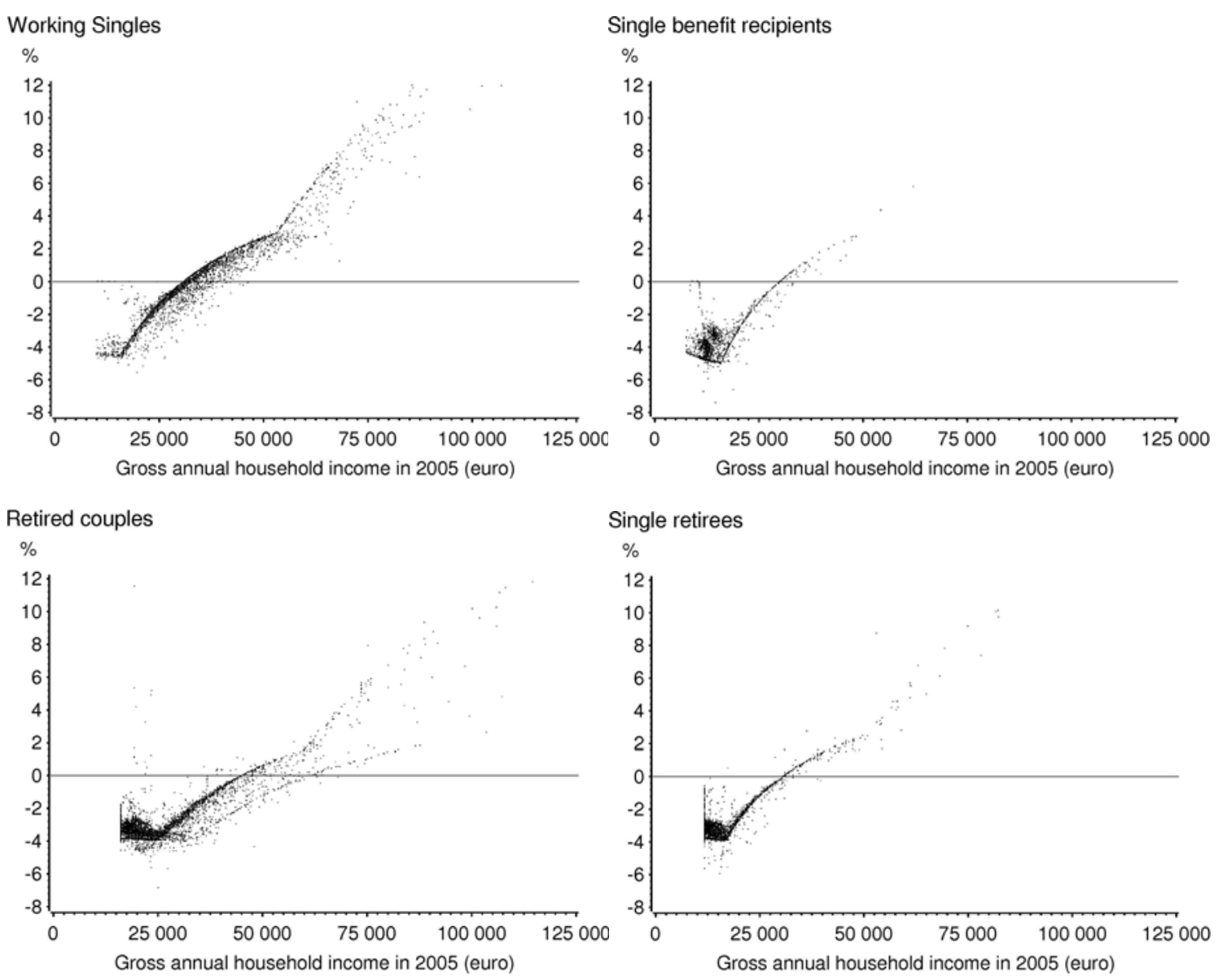

In the second flat tax reform, the higher general tax credit of 1400 euro benefits especially low income groups; the higher tax rate of $43.5 \%$ hurts especially people collecting high incomes. The second flat tax reform yields smaller distributional effects than the first. This is shown in Figure 4.2, which demonstrates the same income effects as in Figure 4.1, but now for the second flat-tax reform. We see that people earning low incomes generally lose only little from the reform (one-earner couples and elderly) or even gain (singles and two-earner couples). For these people the higher credit more than compensates for the increase in the tax rate. For very high income levels, the reduction in the marginal tax from 52 to $43.5 \%$ affects a major share of income. Hence, these people still gain, although it is smaller than under the first reform. The middle income groups typically lose as the rise in the tax rate to $43.5 \%$ applies to the lion's share of their income. The higher tax credit only partially compensates for this. Therefore, the second flat tax reform redistributes the tax burden from very low and very high incomes towards the middle groups. We observe a U-shape pattern for the income effects in Figure 4.2. ${ }^{7}$

\footnotetext{
${ }^{7}$ Since the credit is not paid out as a negative income tax in this proposal, benefit recipients and retired persons cannot always take up the higher credit. This explains the reduction in income for these groups.
} 
The aggregate Theil coefficient does not change compared to the current system. Hence, overall inequality is more or less unaffected.

Figure 5.2

Income effects according to household type of a $43^{1 / 2} \%$ flat tax and a 1400 euro higher tax credit in 2006 (\% changes)
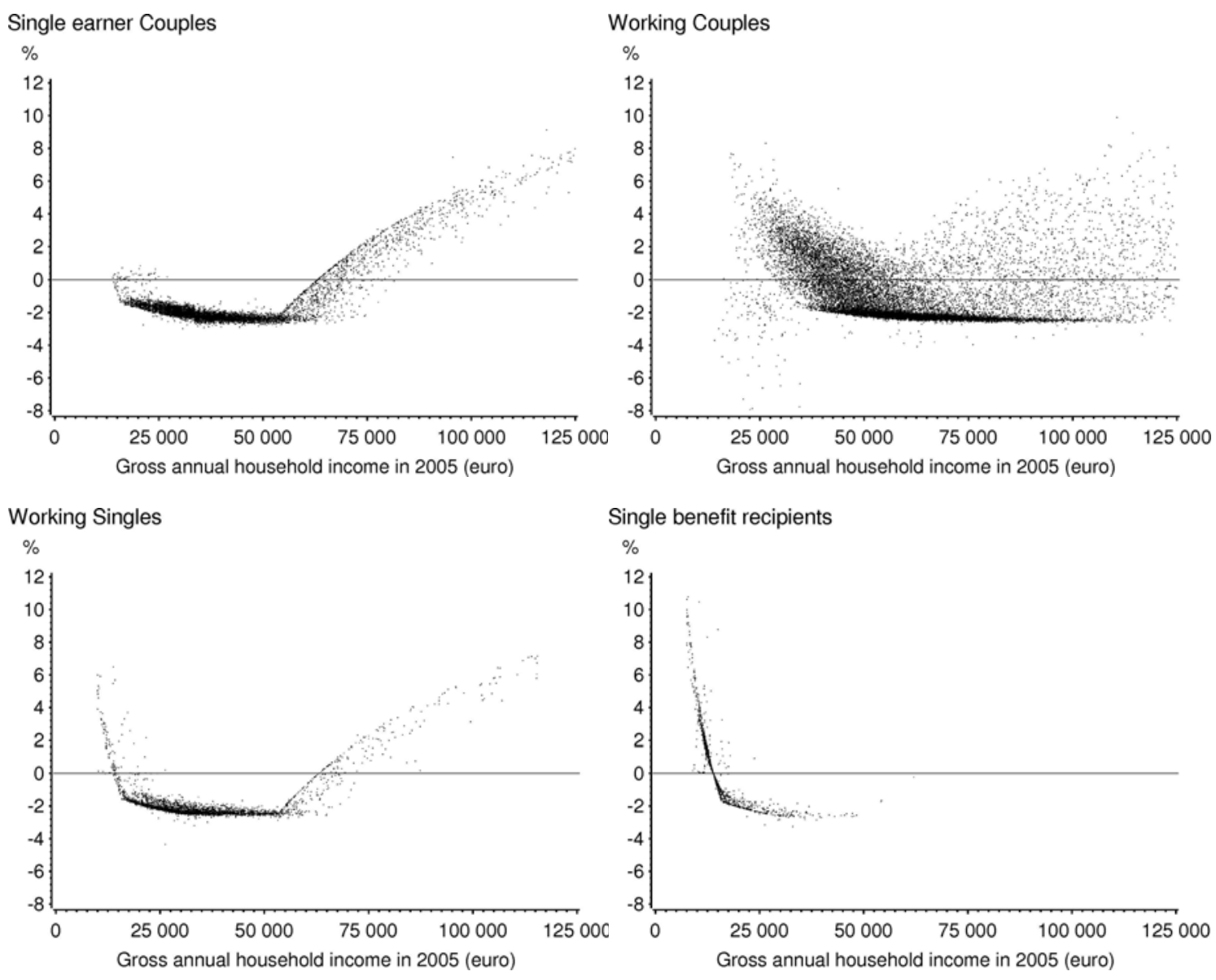

Single benefit recipients
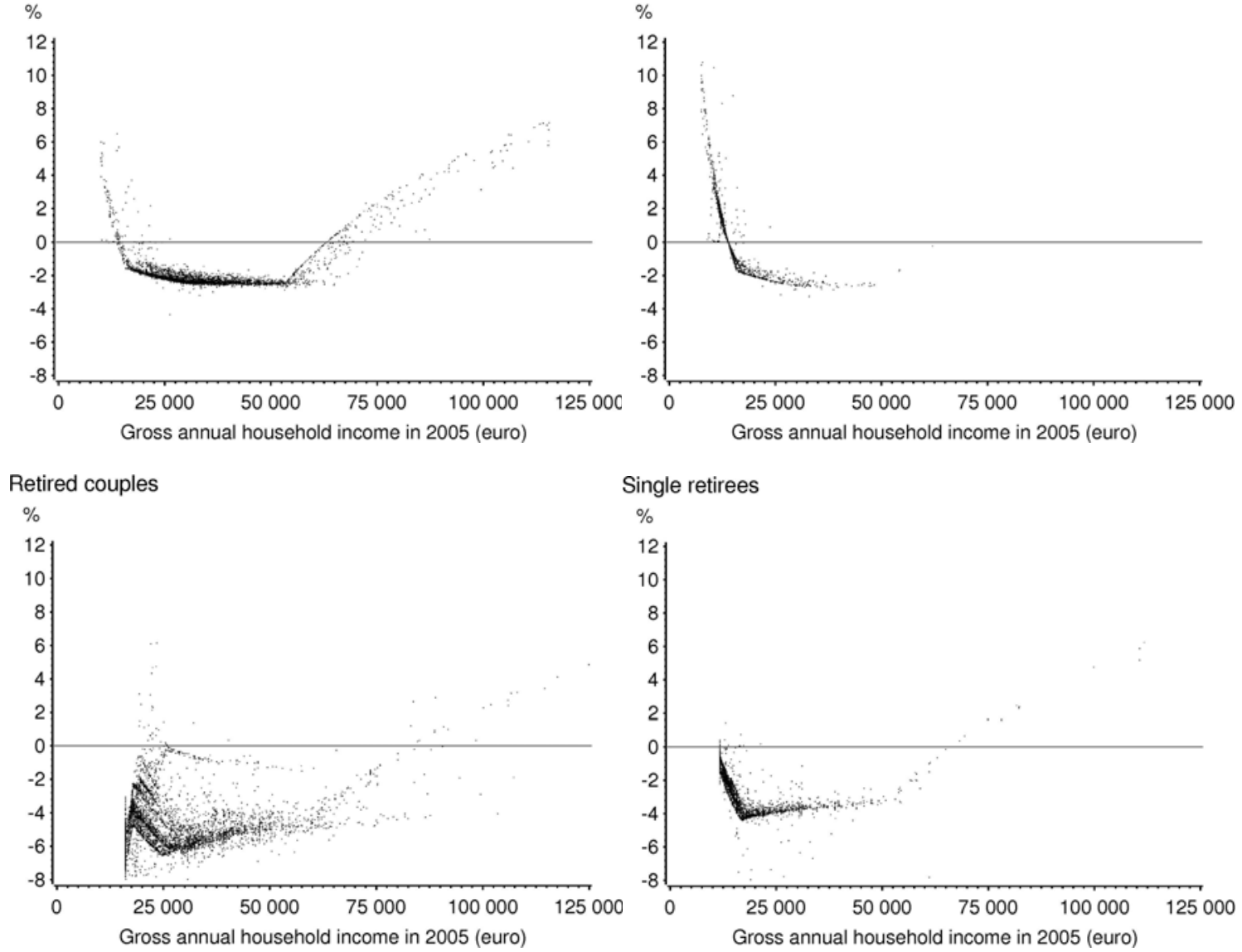


\section{Labour market implications}

Table 4.2 shows the labour market effects of the two flat tax reforms. In the first reform, presented in the first column of Table 4.2, the mean of the marginal tax rate across individuals falls by $2.9 \%$. The lower marginal tax for many people increases aggregate labour supply due to substitution from leisure to consumption. Overall, we find that labour supply expands by $1 \%$. The increase in hours worked does not apply to all individuals. Most primary earners and single persons face lower marginal tax rates as they are taxed at the margin in the higher tax brackets. Hence, these groups raise hours worked. Many secondary earners in couples, however, hold part-time jobs where they are taxed at the margin in the first bracket. The increase in the tax rate from $34 \%$ to $37.5 \%$ in the first bracket discourages non-participating partners to occupy small part-time jobs. Accordingly, the female participation rate drops by $1.7 \%$. Other partners increase their hours worked due to lower marginal tax rates in the higher tax brackets. This compensates for the lower participation rate so that the overall effect of the flat tax reform for the labour supply of partners is negligible.

Lower marginal tax rates also encourage training by increasing income differences between skills. This raises the transition rate from low to high-skilled labour. The share of high-skilled labour supply is found to expand by $0.8 \%$.

The equilibrium unemployment rate falls slightly. This is the result of two offsetting effects. On the one hand, benefit recipients typically collect lower incomes than workers. Hence, the replacement rate falls. This increases job search and reduces the reservation wage in the searchmatching model. Moreover, it moderates wage claims in the bargaining model, where the lower replacement rate reduces the bargaining position of the workers due to a less attractive outside option. On the other hand, the impact of a lower replacement rate is mitigated by the upward effect of the lower marginal tax on wages in the bargaining model. On balance, the first effect dominates so that the unemployment rate falls by $0.1 \%$. The effect is concentrated among the low-skilled where the replacement rate falls most. Overall, we can conclude that the first flat tax reform causes more inequality. At the same time, it reduces distortions in labour supply, training and unemployment. Hence, it illustrates the classical trade-off between equity and efficiency. 


\begin{tabular}{lrr}
\hline Table Error! Style not defined..2 & Long-term effects of two flat tax proposals on the labour market $^{\mathrm{a}}$ \\
& Flat tax $37.5 \%$ & Flat tax $43.5 \%$ \\
& & 0.5 \\
Inequality index (Theil coefficient) & -1.8 & 0.4 \\
Producer wage & 0.2 & 0.4 \\
$\quad$ low skilled & -2.9 & 0.3 \\
$\quad$ high skilled & 1.0 & -0.3 \\
Labour supply in hours & 1.2 & 0.1 \\
$\quad$ primary earners & 0.0 & -0.2 \\
$\quad$ secondary earners & 1.0 & -1.2 \\
$\quad$ single persons & -1.7 & 1.5 \\
Female participation rate & 0.8 & 0.0 \\
Share of high-skilled labour supply & 1.4 & -0.3 \\
Employment & -1.9 & -0.4 \\
$\quad$ low skilled & 2.7 & -0.3 \\
$\quad$ high skilled & -0.1 & -0.1 \\
Unemployment rate (absolute change) & -0.4 & -0.1 \\
$\quad$ low skilled & 0.1 & 0.0 \\
$\quad$ high skilled & 1.6 & -0.3 \\
Production & &
\end{tabular}

The second column of Table 4.2 shows the labour-market effects of the second flat tax reform. Here, we find that the labour supply distortions become larger, rather than smaller: labour supply falls by $0.3 \%$. The reason is that the marginal tax burden is shifted from people at the bottom and top of the income distribution towards the middle incomes. On the one hand, the lower marginal tax at the bottom encourages non-working partners to participate in small parttime jobs. Moreover, high-skilled primary earners who face a lower marginal tax rate raise their hours worked. On the other hand, the higher marginal tax on middle incomes exerts negative effects on hours worked. This latter distortion is relatively large for two reasons. First, it affects the more densely populated group of middle incomes, which renders the distortions larger. Second, it affects secondary earners and singles who feature larger elasticities than male breadwinners. Indeed, the simulations suggest a fall in labour supply of partners and singles of $0.2 \%$ and $1.2 \%$, respectively.

The second flat tax reform no longer increases overall income inequality: the Theil coefficient does not change. Accordingly the effect on human capital formation and, therefore, the share of high-skilled labour supply is negligible.

The unemployment rate drops marginally due to the reduction in the average tax on lowskilled labour. Due to the fall in labour supply, aggregate employment falls however by $0.3 \%$.

Overall, the second flat tax reform avoids an increase in aggregate inequality, but fails to yield positive labour market effects. In fact, it comes along with negative effects on labour 
supply and employment. It suggests that the flat tax achieves the redistributive goals in a less efficient way than the current Dutch tax system.

This result is consistent with the optimal tax literature, which suggests that a non-linear tax structure is more efficient than a linear (flat) tax system in reducing inequality. Our simulations capture the same mechanisms as present in the optimal tax models, but add two other reasons why the current piecewise linear tax structure is more efficient than a flat tax. First, low marginal tax rates for lower incomes are efficient because females -- who in the Netherlands massively occupy part-time jobs -- feature higher labour supply elasticities than males. Second, some degree of tax progression is efficient because it mitigates pre-existing distortions on the labour market. In particular, marginal taxes moderate wages and reduce the unemployment rate, thus producing more efficient labour market outcomes.

\section{Tax arbitrage and simplification}

Flat tax proposals are also motivated by other arguments than their labour-market implications. In this section, we discuss these arguments and explore whether they can validate the introduction of a flat tax.

Under a flat income tax, the government requires only information about aggregate labour income to determine tax liabilities. Indeed, there is no need for an individualised tax rate so that the tax can be levied simply as a payroll tax on employers. This may save on administrative and compliance costs. However, these savings on administrative costs evaporate if the government still needs to collect information on household or individual incomes for the determination of income dependent benefits, tax credits, subsidies or tax exemptions. Related to this is the argument of increased transparency of a flat tax for taxpayers. Also this ignores the income dependent schemes. In fact, the complexity and lack of transparency of the tax system is not caused by the rate structure, but by the determination of taxable income. The difficulties in determining taxable income arise due to exemptions, deductions and credits to, for example, housing, pensions, schooling, children, cars, traveling costs, and the like. Removing these parts of the tax code can simplify the system and broaden the tax base considerably, but this has nothing to do with adopting a flat tax rate (see also Keen et al., 2006).

Another possible advantage of the flat tax is that it reduces tax arbitrage. For instance, the flat tax is neutral with respect to the division of lifetime income across years and thus reduces intertemporal tax arbitrage. However, the opportunities for intertemporal arbitrage are already mitigated as in the current system people have the option to divide their income equally across three subsequent years. Still, intertemporal arbitrage remains important as the Dutch tax system applies a tax rate that is $17.9 \%$-points lower for people above 65 than for people below 65 . This encourages postponement of income to the old age. Yet, this form of intertemporal arbitrage does not depend on the progressive tax structure, but on the low tax on elderly. There are also other forms of tax arbitrage, e.g. between corporate and personal income or between labour and 
capital income. As long as the flat tax applies only to labour income and different tax rates apply to different sources of income, these forms of arbitrage will not disappear, however. Indeed, it would require an integrated approach along the lines of the Hall-Rabushka proposal for a flat tax, not just a flat rate on labour income, to alleviate this arbitrage.

A flat rate is also argued to be more neutral with respect to the division of labour between partners in a household. This is a whimsical argument. Rising marginal tax rates give excessive incentives to men to engage in household production compared to women -- given that men earn more than women. Under a flat tax, in contrast, the marginal tax rate will be equal for both partners. This form of neutrality is, however, inefficient when differences in labour elasticities between men and women are taken into account. Indeed, Ramsey principles suggest that elastic tax bases should be taxed less than inelastic ones so that marginal tax rates for women should be lower than for men (Boskin and Sheshinsky, 1983). Accordingly, the government needs to trade off distortions in the division of labour within families and distortions in the labour market.

A flat tax is sometimes said to reduce political opportunism, which arises due to special interests and lobby groups. Again, this argument is flawed because not the rate structure serves special interest groups, but the myriad of exceptions, exemptions and deductions does. Changing the rate structure is not a targeted policy to serve the special interest groups, too costly in budgetary terms and completely transparent to the general public. A flat tax will therefore not fundamentally affect political distortions.

\section{Conclusions}

This paper analyzes the income and labour-market effects of the introduction of a flat tax rate on income from labour and self employment in the Netherlands. If income inequality is broadly maintained at its current level, our simulations suggest that a flat tax will not alleviate labour market distortions. Instead, we find that labour supply and employment will decline. The reason is that the reform shifts the marginal tax burden towards the densely populated middle groups and to partners and singles that feature high elasticities of labour supply. A flat tax hurts labour supply incentives more severely than the current system of increasing marginal tax rates. Our simulations also reveal that labour supply distortions can be mitigated if income inequality increases. This illustrates the classical trade-off between equity and efficiency.

Our findings are consistent with optimal tax literature. It emphasises that a non-linear income tax is more efficient than a linear (flat) income tax in achieving redistributive goals. This is because the non-linear tax system better uses information on the density of the income distribution and differences in tax sensitivities to redistribute income. Replacing a non-linear tax by a flat tax therefore boils down to replacing a more efficient tax by instrument a less efficient tax instrument to redistribute incomes. 
Other arguments in favour of a flat tax could be its larger simplicity or lesser tax arbitrage. However, this requires other reforms, rather than a mere flattening of the tax rate on labour income. Indeed, simplification of the tax code calls for a more uniform treatment of different types of income and the elimination of tax exemptions and tax deductions. Reducing arbitrage calls for a more uniform treatment of different sources of income. Hence, irrespective of one's political preferences on income redistribution, pleas for a flat income tax rate on labour lack a sound economic motivation.

\section{References}

Boskin, M.J., and E. Sheshinski (1983), “Optimal Tax Treatment for the Family”, Journal of Public Economics, 20, 281-297.

Bovenberg, A.L., J.J. Graafland, and R.A. de Mooij (2000), “Tax Reform and the Dutch Labor Market”, Journal of Public Economics, 78, 193-214.

Bovenberg, A.L., and B. Jacobs (2005), “Redistribution and Education Subsidies are Siamese Twins”, Journal of Public Economics, 89, 2005-2035.

Diamond, P.A. (1998), “Optimal Income Taxation: an Example with a U-shaped Pattern of Optimal Marginal Tax rates”, American Economic Review 88, (1), 83 -95.

Evers, M., R.A. de Mooij, and D.J. van Vuuren (2005), "What Explains the Variation in Estimates of Labour Supply Elasticities?”, CPB Discussion Paper no. 51, The Hague.

Ewijk, C. van, and P. J. G. Tang (2000), “Efficient Progressive Taxes and Education Subsidies”, CPB Research Memorandum no 170, The Hague.

Graafland, J.J., and F.H. Huizinga (1999), “Taxes and Benefits in a Non-Linear Wage Equation”, De Economist 147, 39-54.

Graafland, J.J., R.A. de Mooij, A.G.H. Nibbelink and A. Nieuwenhuis (2001), MIMICing Tax Policies and the Labour Market , North-Holland: Elsevier.

Jacobs, B. (2005), Optimal Income Taxation with Endogenous Human Capital, Journal of Public Economic Theory, 7, (2), 295-315.

Keen, M., Y. Kim and R. Varsano, 2006, The 'flat tax(es)': principles and evidence, IMF Working Paper 06/218.

Kuhry, B. (1998), “Trends in Onderwijsdeelname”, Sociale en Culturele Studies, SCP, The Hague.

Mirrlees, J.A. (1971), “An Exploration in the Theory of Optimum Income Taxation”, Review of Economic Studies, 38, 175-208.

Saez, E. (2001), “Using Elasticities to Derive Optimal Income Tax Rates”, Review of Economic Studies, 68 (1), 205-229.

Saez, E. (2002), Optimal Income Transfer Programs: Intensive versus Extensive Labor Supply Responses, Quarterly Journal of Economics, 117, 1039 -1073.

Seade, J.K. (1977), “On the shape of optimal tax schedules”, Journal of Public Economics, 7, 203-236.

Tuomala, M. (1990), Optimal Income Tax and Redistribution, Oxford: Clarendon Press. 
Tyrvainen, T., (1995), “Real Wage Resistance and Unemployment: Multivariate Analysis of Cointegrating Relations in 10 OECD Countries”, OECD Working Paper No. 10, Paris. 